Птахіна Ольга Миколаївна

Д3 «Луганський національний університет імені Тараса Шевченка» м. Старобільськ

\title{
НЕОБХІДНІСТЬ ФОРМУВАННЯ ПРОФЕСІЙНОЇ МОБІЛЬНОСТІ МАЙБУТНЬОГО ФАХІВЦЯ ПІД ЧАС НАВЧАННЯ У ВИЩИХ НАВЧАЛЬНИХ ЗАКЛАДАХ
}

Сучасний стан суспільного розвитку змушуе формулювати принципово нові пріоритети в підготовиі сучасного фахівия. Збільшення можливостей $і$ потреб до особистого розвитку фахівия та необхідності оволодіння новими професіями, які постійно з'являються на сучасному ринку прачі, зумовили необхідність формування професійної мобільності майбутнього фахівия під час навчання у вищих навчальних закладах. Підготовка конкурентноспроможних, професійно мобільних та компетентних фахівиів є стратегічним завданням украӥнської системи вищої освіти. У статті розглянуто сутність професійної мобільності, етапи формування та причини, що сприяли необхідності формування професійної мобільності майбутнього фахівия під час навчання $у$ вищих навчальних закладах.

Ключові слова: професійна мобільсть, професійна компетентність, етапи формування професійної мобільності.

Проблема, іï зв'язок із важливими науковими чи практичними завданнями. Зміни, які відбуваються сьогодні в Україні, пов'язані із збільшенням можливостей і потреб особистісного розвитку людини, поглибленням іiі професійної мобільності в сучасному суспільстві, необхідністю оволодіння новими професіями, які з'являються на ринку праці. У такій ситуації успіх професійної підготовки майбутніх фахівців значною мірою визначається здатністю вищої освіти гнучко реагувати на умови, що постійно змінюються. Сучасний фахівець - це фахівець, який здатний до мобільного реагування в своїй професійній діяльності на постійно змінювані потреби суспільства, відкритий до всього нового, який спроможний швидко адаптуватися в складних умовах професійної та соціальної дійсності, самостійно і відповідально приймати рішення, орієнтований на успіх і постійне самовдосконалення. Тому проблема формування професійної мобільності під час навчання у вищих навчальних закладах набуває особливого значення. 
Ціль статті - обгрунтування необхідності формування професійної мобільності майбутніх фахівців під час навчання у вищих навчальних закладах та іï вплив на умови їх професійного розвитку.

Аналіз публікацій (виділення невирішених проблем). Питанню мобільності присвячено праці батьох науковців: педагогічні аспекти професійної мобільності розглідали В. Андрєєв, Н. Василенко, O. Горанська, Т. Гордєєва, I. Зимня; педагогічні умови процесу формування професійної мобільності вивчали Є. Іванченко, Н. Кожемякіна, Н. Латуша, Л. Сушенцева; вплив зовнішніх та внутрішніх чинників розглядали Л. Амірова, О. Любімова, В. Міщенко та інші.

Причиною великої кількості праць з цього питання є те, що нині віддається перевага фахівцям, які володіють декількома суміжними професіями.

Виклад основного матеріалу, обгрунтування результатів дослідження. Сьогодні професійна мобільність відіграє надзвичайно важливу роль у сучасному суспільстві, адже вона прямо пов'язана 3 рівнем професійної підготовки особистості. Основним чинником, що обумовлює характер і зміст професійної мобільності, є динамічні зміни в розвитку суспільства. Європейський розвиток країни, іiі місце на світовому ринку праці прямо пропорційно залежить від ефективності системи вищої освіти, що забезпечує підготовку майбутніх кваліфікованих фахівців, тому професійна мобільність набуває особливого значення в сучасних умовах. У більшості випадків результатом професійної мобільності стає ефективна трудова діяльність, яка задовольняє потреби особистості.

Науковці розглядають професійну мобільність як: якість особистості, що дозволяє їй бути соціально активною, конкурентоспроможною, професійно-компетентною, здатною до саморозвитку й модернізації власної діяльності та зміни видів діяльності; здатність швидко змінювати вид праці, переключатися на іншу діяльність у зв'язку зі змінами техніки й технології виробництва. Вона виявляється у володінні системою узагальнених прийомів професійної праці та застосуванні їх для успішного виконання будьякого завдання $[1 ; 3 ; 6]$. У педагогічній енциклопедії визначено професійну мобільність як можливість і здатність успішно переключатися на іншу діяльність або змінювати вид праці [4].

Серед вимог, що висуваються сьогодні до майбутнього фахівця, виділяють такі: особистісна компетентність - сукупність компетенцій, що стосуються особистості (набір характерних якостей окремої особистості): ініціативність, впевненість у собі, здатність до творчості, здатність пристосовуватися до середовища, що змінюється, готовність до ризику та ін.; професійна компетентність - сукупність компетенцій 


\section{Збірник наукових статей}

людини, що стосуються іï професії (здатність до виконання роботи): знання, уміння і досвід, якими вона володіє у своїй професії; соціальна компетентність - сукупність компетенцій людини, що стосуються іiі соціального життя (вміння жити i працювати в соціумі, комунікабельність, здатність вживатися/працювати 3 іншими людьми, здатність переборювати конфлікти, здатність до самоорганізації), постановка i досягнення цілей, прийняття рішень та ін.; особливі переваги особистості, які роблять людину унікальною і можуть бути корисні, цікаві, наприклад, роботодавцю [3].

Професійна мобільність визначається готовністю і вмінням людини вчитися самостійно, на базі отриманої освіти засвоювати нові досягнення у професійній сфері. У цьому процесі особлива роль належить мотивації особистості, їі спрямованості на засвоєння нового, самоосвіті, самовдосконаленні. Формування професійної мобільності майбутніх фахівців у вищіх навчальних закладах залежить від мотивації студента, його активності, рівня лідерських якостей, зацікавленості у навчальних успіхах, відповідності рівня підготовки до вимог на ринку праці, а отже і конкурентоспроможності фахівця. Тому підготовка професійно мобільних фахівців передбачає проходження кількох етапів. Перший етап передбачає формування базових професійних компетенцій, котрі стають підгрунтям для формування професійної мобільності. Наступний етап передбачає розвиток особистісних якостей таких, які сприяють професійному саморозвитку: особистісна адаптивність до умов ринку праці, відповідальність за свою діяльність, вольові якості, комунікативні уміння, адекватна самооцінка.

Професійна мобільність проявляється в професійній діяльності і забезпечує самовизначення й самореалізацію на основі сформованості професійних компетенцій і професійного розвитку.

Професійна компетентність дає змогу фахівцю успішно виконувати різноманітні види професійної діяльності, виявляє рівень знань i практичних умінь, ступінь сформованості професійної культури спеціаліста і визначає результати його роботи. Професійна компетентність $є$ ознакою й головним критерієм професійної підготовленості та здатності суб'єкта праці виконувати свої професійні обов'язки відповідно до обійманої посади.

Професійний розвиток передбачає зростання, становлення професійно значущих особистісних якостей і здібностей, знань та вмінь. Професійний розвиток тісно пов'язаний з особистісним, саме особистісні якості у процесі професійної діяльності забезпечують спрямованість особистості на самовдосконалення.

Необхідність формування професійної мобільності майбутнього фахівця в сучасних умовах під час навчання у вищих навчальних 
закладах науковці зумовлюють цілим рядом причин, які можна розподілити на внутрішні та зовнішні. Внутрішні причини формування професійної мобільності - це якості особистості, зовнішні зміни можуть бути викликані необхідністю зміни професії, у результаті зміни місця проживання, нових сімейних обставин, погіршення стану здоров'я, а також глобальми: економічним і соціальним станом держави, науково-технічним прогресом, розвитком інформаційних технологій, тенденціями на ринку праці і т.д.

Висновки. На сучасному етапі розвитку суспільства науковці розглядають проблему професійної мобільності 3 позицій компетентнісного підходу, тобто в основі формування професійної мобільності майбутніх фахівців є професійні компетенції, які мають широкий радіус дії та дозволяють виходити за межі однієї групи професій. Причинами необхідності формування професійної мобільності у вищих навчальних закладах в сучасних умовах $є$ те, що майбутній фахівець: виступає активним суб'єктом ринку праці, вільно розпоряджається своїм головним капіталом - своєю кваліфікацією; має отримувати таку базову освіту, яка буде дозволяти йому відносно легко опановувати нові професії в майбутньому. За статистикою приблизно лише $20 \%$ зайнятого населення працює за отриманою спеціальністю, а 42\% молодих фахівів змінюють свої професії у перші два роки після закінчення вищого навчального закладу.

Отже, професійну мобільність можна розглядати як одну із форм адаптації молодого фахівця до нових умов, зумовлених зовнішніми або внутрішніми факторами. Тільки завдяки поєднанню процесів формування професійною мобільності під час навчання у вищих навчальних закладах та постійному самовдосконаленню особистості можна досягти ефективної професійної мобільності й високої професійної компетентності.

Формування професійної мобільності набуває важливого значення в освітньому процесі у вищих навчальних закладах та передбачає: формування універсальних навичок діяльності, що забезпечують мобільність як якість особистості; орієнтацію на інноваційну діяльність; забезпечення якісної фахової підготовки як бази для можливого освоєння інших професій.

\section{Література}

1. Гордієнко М. Г. Професійна мобільність у наукових дослідженнях / М. Г. Гордієнко // Педагогіка і психологія. - 2011. № 4. - С. 106-114.

2. Грицькова Н. В. Професійна мобільність фахівця: сутність та структура / Н. В. Грицькова // Вісник ЛНУ ім. Т. Шевченка. - 2010. № 12 (199). - С. 25-32. 
3. Іванченко С. А. Професійна мобільність майбутніх фахівців: навч. посібник / Є. А. Іванченко. - Одеса : СМИЛ, 2014. - 120 с

4. Педагогика: большая современная энциклопедия [Текст]. Минск: Современное слово, 2005. - 720 с.

5. Пілецька Л. С. Вплив соціально-психологічної адаптації на професійну мобільність особистості / Л. С. Пілецька // Теоретичні і прикладні проблеми психології. - 2012. - № 3 (29). - С. 227-234.

6. Сушенцева Л. Л. Професійна мобільність як соціологічна категорія: мат. науч.-пр. конф. / Л. Л. Сушенцева, Т. С. Сулима // Actual questions and problems of development of social sciences. - Kielce: Holy Cross University, 2016. - P. 82-85.

7. Шпекторенко I. В. Управління професійною мобільністю державних службовців : автореф. дис...д-ра наук 3 державного управління: спец. 25.00.03 / Ігор Валентинович Шпекторенко. - К. : Інститут законодавства Верховної Ради України, 2012. - 38 с.

\section{Ольга Птахина. Необходимость формирования} профессиональной мобильности будущего специалиста во время обучения в высших учебных заведениях.

В современных условиях общественного развития возникает необходимость формулирования принципиально новых приоритетов в подготовке современного специалиста. Увеличение возможностей и потребностей к личному развитию специилиста и необходимость овладения новыми профессиями, которые постоянно появляются на современном рынке труда, обусловили необходимость формирования профессиональной мобильности будущего специалиста во время обучения в высших учебных заведениях. Подготовка конкурентоспособных, профессионально мобильных и компетентных специалистов является стратегической задачей украинской системь выстего образования. B статье рассмотрень сущность профессиональной мобильности, этапь формирования и причины, которые привели к необходимости формирования профессиональной мобильности будущего специалиста во время обучения в высших учебных заведениях.

Ключевье слова: профессиональная мобильсть, профессиональная компетентность, этапь формирования профессиональной мобильности.

Olga Ptakhina. Necessity of formation professional mobility of the future specialist during studies in the higher educational establishments.

In modern conditions of social development, there arises the need to formulate fundamentally new priorities in the training of a modern 
Психолого-педагогічні проблеми становлення сучасного фахівця Випуск 2018

specialist. Increasing the opportunities and needs for personal development of a specialist and the need to master new professions that constantly appear on the modern labor market have necessitated the formation of professional mobility of the future specialist during training in higher education institutions. The preparation of competitive, professionally mobile and competent specialists is a strategic objective of the Ukrainian higher education system. The article considers the essence of professional mobility, the stages of formation and the reasons that led to the necessity of forming the professional mobility for the future specialist while studying in higher educational institutions.

Keywords: professional mobility, professional competence, stages of formation of professional mobility.

Стаття надійшла до редакційної колегії 07.05.2018

Прийнято до друку 08.05.2018

\section{Інформація про автора:}

Птахіна Ольга Миколаївна - кандидат педагогічних наук, доцент, ДЗ «Луганський національний університет імені Тараса Шевченка», м. Старобільськ. 